\title{
Socio-Economic Research on Housing in the Czech Republic
}

\author{
MARTINA MIKESZOVÁ* \\ Institute of Sociology, Academy of Sciences of the Czech Republic, Prague
}

\begin{abstract}
The article presents a review of the research activities of the SocioEconomics of Housing research team. The Socio-economics of Housing team is one of the research teams at the Institute of Sociology of the Academy of Sciences of the Czech Republic. The main research activities of the team include sociological research concerning attitudes towards housing in the Czech Republic, international comparisons of housing policies and social housing systems, and econometric simulations of policy reforms, like rent deregulation, the introduction of housing allowance and social housing, housing finance, housing market efficiency, and house price indices.
\end{abstract}

Keywords: housing research, housing market, housing policy, housing finance

Sociologický časopis/Czech Sociological Review, 2007, Vol. 43, No. 3: 637-646

The Socio-Economics of Housing research team was established by the economist and sociologist Martin Lux at the Institute of Sociology, Academy of Sciences of the Czech Republic, in 2000. In the beginning, it focused on studying housing expenditures (housing consumption), but gradually its activity was extended to take in other housing research areas. Its main research activities now relate to both the social and the economic aspects of housing and thus include such diverse topics as housing attitudes, housing preferences, international comparisons of housing policies and social housing systems, and econometric simulations of policy reforms, like rent deregulation, the introduction of housing allowance and social housing, housing finance, housing market efficiency, and house price indices. This essay presents an overview of this research, which aims at examining housing as both an economic and a social (merit) good.

As in other post-communist countries, the Czech transition to a market economy after 1989 has been accompanied by changes affecting housing affordability and accessibility, but real housing policy reform has only been partially implemented because it was not made a priority in the initial reform package [Lux 2000, 2001]. Under the former regime, housing was subject to tight state

\footnotetext{
* Direct all correspondence to: Martina Mikeszová, Institute of Sociology, Academy of Sciences of the Czech Republic, Jilská 1, 11000 Prague 1, Czech Republic, e-mail: Martina. Mikeszova@soc.cas.cz
} 
control. All privately owned apartment-housing stock was nationalised and cooperative housing lost its independence. Housing cooperatives fell under state administration, and all rents were controlled by the state. The share of state rental flats out of the total housing stock grew rapidly after extensive housing construction financed from the state budget was undertaken. However, this housing was of dubious quality: large pre-fab housing estates gave rise to a new type of city [Lux 2000].

Since 1989, many of the nationalised state-owned apartment buildings were returned to their original owners or the owners' heirs through the restitution laws. The remaining state-owned flats were transferred free-of-charge to the ownership of the municipalities. However, the central government decided to maintain the 'old'-style system of untargeted state rent control in both private rental (restituted) housing and municipal housing. Since 1992 a very slow process of rent deregulation has been under way, and since 1993 it has been permitted to charge market rents for new tenancies. As the management of housing posed too high a financial burden on many municipalities (owing to the low, regulated rents, the absence of operation subsidies, and the high maintenance debt inherited from previous regime), many municipalities decided to sell part or all of their housing stock. Municipal housing was most often privatised by selling a flat to its current occupants - initially to 'tenant cooperatives' and, since 1994, to tenants in the newly established homeowners associations - at an advantageous price. Cooperative housing became in fact a part of the homeownership sector because co-op members gained the right to 'sell' their flat (in reality, to transfer, against payment, their cooperative share) on the free market and to transfer the cooperative flat to private ownership at no cost. Lux [2000] has noted the following problems connected with housing policy reform and privatisation:

- the continued existence of untargeted rent regulation;

- the lack of political will to introduce rent deregulation and establish a new, 'second-generation' rent-control system ('locally appropriate rent');

- an inadequate system of control over the use of municipal rental flats (leading to widespread black market practices);

- tenants with rent-control contracts continue to enjoy the old and disproportionately strong security of tenure guaranteed in the Civil Code, whereby tenants become 'quasi-homeowners';

- the absence of a legal definition of social housing and governmental incentives for private not-for-profit investments in the field of social housing.

In Lux's words [2000: 4], "“the hitch" of Czech housing is not, in contradiction with the established belief, in low financial affordability of owner-occupied housing, which is "expensive" even for the majority of young and lower-income households in EU countries; the hitch is in the non-existence of functional rental housing'.

Based on an in-depth analysis of household housing expenditures in the Czech Republic (using the 'Family Budget Survey' datasets), it is possible to de- 
fine three main social tensions between households in significantly unequal positions in the housing market [Lux 2000]:

- the tension between households without economically active members and households with at least one economically active member, based on the gap in their average net rent-to-income ratios,

- the tension between landlords and their tenants, resulting from rent controls, and

- the tension between tenants living in rent-controlled flats and tenants living in 'market-rent' rental flats.

Tenants in rent-controlled flats enjoy strong legal security of tenure and benefit from low rents; conversely, households forced to live in the market rental sector effectively obtain no state financial assistance and have only limited security of tenure (due to fixed-term rental contracts). Moreover, the share of lowerincome households out of the total number of households living in the municipal rent-controlled housing sector is not significantly higher than in other tenures. Regulated rent prices were too low to cover even basic flat/house maintenance costs and they formed a marginal part of household budgets, when compared to the situation in EU countries.

In their research projects the Socio-Economics of Housing team has used the methodology of both quantitative and qualitative surveys and has drawn on a wide range of national and international quantitative data sets. In particular they have drawn on data from the annual 'Family Budget Surveys' conducted by the Czech Statistical Office (ČSÚ), data from the Institute of Regional Information (IRI) on market rents, and data from the survey 'Housing Attitudes in the Czech Republic 2001'1 conducted directly by the research team. 'Housing Attitudes in the Czech Republic 2001' was a comprehensive survey of housing attitudes among the Czech population conducted in June and July 2001. Another survey, albeit less extensive, examined the housing attitudes of people living in market rental housing in Prague and made it possible to compare the attitudes of the 'majority' population with the attitudes of this specific group of citizens.

In 'Housing Standards of Czech Households and Their Potential for Growth in View of the Experience of Developed Countries of the European Union' (a project funded by the Grant Agency of the Czech Republic), the research aimed to conduct comprehensive analyses of the financial affordability of housing and housing expenditures in connection with general changes in the consumer behaviour of Czech households; analyses of the social effectiveness and economic efficiency of current and potential housing policy instruments directed towards increasing financial affordability of housing (social housing, housing allowances);

\footnotetext{
1 'Housing Attitudes in the Czech Republic 2001': The survey was carried out in June and July 2001; interviews were conducted with 3564 persons aged 18 and older selected using the quota sampling method. The data files are stored in the Czech Sociological Data Archive (SDA).
} 
analyses of the social and economic consequences of existing or potential supplementary state interventions influencing housing standards of Czech households (regeneration of the residential environment, civic/tenant participation in housing administration, the modernisation of housing, private-public partnership in housing services or social housing). Within the framework of this project three studies were published between 2003 and 2005 as a series titled Housing Standards. The first publication, Housing Standards 2002/03: Financial Affordability and Attitudes to Housing [Lux, Sunega, Kostelecký and Čermák 2003] concentrates primarily on the issue of the financial affordability of housing and housing costs in the context of the general consumer expenditures of Czech households, and on the attitudes of the Czech population towards housing affordability and housing policy in general.

The most significant growth in the housing expenditures-to-income ratio of Czech households living in the rent-controlled housing sector was recorded between 1991 and 1993 and between 1997 and 1999, mainly as a result of energy and utility price liberalisation [Lux 2000; Lux et al. 2003; Sunega 2003]. Households of retirees, singles (especially women), single-parent families, or families without an economically active member were categories that throughout the period under observation were the most encumbered with housing expenses (on average, they spent the greatest part of their income on housing). However, especially in the case of households of singles and retirees, it was found that the high level of the expenditures-to-income ratio was often a consequence of the over-consumption of housing, i.e. of the fact that they live in apartments too large for them. If appropriate conditions existed to enable these households to rationalise their housing consumption, the problem of the poor financial affordability of rent-controlled housing would almost disappear. It was found that during the 1990s the difference in the level of the expenditure-to-income ratios of households with the highest and the lowest income increased, and the size of the city was discovered to have a growing impact on the level of the ratio (households from bigger municipalities spend a greater portion of their income on housing than households living in a smaller municipalities or in rural areas).

In owner-occupied housing, like rental housing, the most vulnerable groups are households of retirees, singles, incomplete families with children and complete families with children, whose caretaker is not economically active [Lux et al. 2003; Sunega 2003]. However, the financial burden on these households is much lower compared to households in the rental-housing sector. In addition, for households from the owner-occupied housing sector, their real property is a dormant source of income, which they can use to solve their housing issue. All the indicators show that the year 1999 (or more precisely the period between the 1997 and 1999) represented a turning point, after which the purchase of owner-occupied housing became more affordable for the average family. Even though the accessibility of new owner-occupied housing decreased between 1991 and 2001, state subsidies (interest relief on a mortgage credit) eliminated this negative trend. 
The attitudes of respondents and their evaluation of the burden of housing expenses proved that households classified using objective data as the most vulnerable (retirees) take a similar view of themselves [Lux et al. 2003; Sunega 2003]. In terms of tenure, the most negative statements on the burden of housing expenses came from people living in rental housing and people living in temporary accommodation (sub-tenants, people living in lodging houses, dormitories, etc.). With regard to housing satisfaction, in the 'Housing Attitudes in the Czech Republic 2001' survey the vast majority of Czech citizens claimed to be satisfied with their housing (more than $80 \%$ of respondents rated their satisfaction between 1 and 5 on a scale of 10), but only $27 \%$ of respondents were satisfied with the current situation in housing in the Czech Republic in general [Lux 2003]. This discrepancy can be explained by the inequalities in the housing market that are not adequately targeted by a state housing policy that has been pursuing shortterm more than long-term goals. The 'insider-outsider' tension (for example, between tenants with low, regulated rents and tenants with several times higher market rents) is particularly strong in the Czech environment.

Housing is an essentially private matter, but it is also an area strongly influenced by the state, as reflected in the title of the book Housing - Res Publica [Lux et al. 2002]. The goal of the governments in developed countries is usually to assure that housing is financially affordable to all groups of citizens. In principle, there are two ways in which the state can promote, by means of wealth redistribution, greater equality in the housing market and in this way increase the affordability of housing for households with low or average incomes: direct cash allowances, which increase the income of families in need (the housing allowance, also called demand-side subsidies or per capita subsidies), or allowances to decrease housing expenses and thus decrease the expenses of households in need (subsidies for construction, reconstruction, or for social housing leading to rents fixed at belowmarket prices, i.e. so-called supply-side subsidies or brick and mortar subsidies) [Lux et al. 2002; Lux 2003].

Housing - Res Publica [Lux et al. 2002] is a detailed source of information about systems of social housing and housing allowances in countries of the European Union (and other developed countries) and examines inspiring instruments that could be used in the Czech environment. The authors also provide a rather specific description of how these instruments are used, and they present the results of econometric simulations of alternative scenario on housing policy reform in the Czech Republic. Central and local housing policy reforms in different post-communist Central and Eastern European countries are largely described and evaluated in the book Housing Policy: An End or A New Beginning? [Lux 2002a], which was prepared under the 'Local Government Policy Partnership' programme and published in Budapest. Studies from six selected CEE countries (Czech Republic, Poland, Slovakia, Romania, Estonia and Bulgaria) describe, for example, different patterns of housing privatisation during the economic transition and evaluate efficiency and the effectiveness of different policy reforms in selected transitional countries. 
Unlike the first publication in the Housing Standards series, which was more descriptive in nature, the second publication, Housing Standards 2003/2004: Housing Policy in the Czech Republic - More Efficient and More Effective [Lux et al. 2004] concentrates on identifying the most suitable housing-policy instruments for the Czech environment. The first question the authors posed is whether there is a housing shortage in the Czech Republic, the answer to which depends largely on how housing shortage is defined and which approach is used to conceptualise housing needs. The spatial approach focuses on the analysis of the availability of housing, while the market-oriented approach is related to the affordability of housing. Lux et al. [2004] concluded that in general there is no housing shortage in the Czech Republic; with respect to housing stock availability indicators, the situation is comparable to several Western European countries. Nevertheless, the Czech Republic does lag significantly behind Western European countries in terms of the quality of the existing housing stock. The claim that there is no housing shortage in the Czech Republic is however a generalisation, as the situation varies regionally. Local housing markets are strongly influenced by the housing policy of the previous governments (especially the mass construction of prefab blocks of dwellings in the 1970s and 1980s) and therefore the discrepancy between the geographical diversification of the housing stock and the situation in the labour market poses a serious problem.

One of the main dilemmas of Czech housing policy is the relationship between the continued privatisation of the municipal housing stock on the one hand and continued rent controls on the other. Untargeted rent controls, which are still in effect in the Czech Republic, reflects neither the real value of the property nor (particularly) the social need of the supported households, and naturally results in a largely artificial lack of flats and the deterioration of the housing stock. It distorts the functioning of the housing market, pushes private investment out of the rental-housing sector, pushes up the so-called market rent to highly disequilibrious levels, and is the source of a deep social injustice between the 'privileged' stratum of people living in regulated flats (who are very often relatively rich) and the 'unprivileged' stratum of people living in market-rental flats or their own housing (very often relatively poor) [Lux et al. 2002]. In the 1960s and 1970s developed countries in the EU began almost universally to abandon the model of untargeted rent controls, also called 'the first-generation rent-control system' and replaced it with 'second-generation rent-control systems', which allow for much greater differentiation of rent levels (according to the property's value) and bring them closer to market levels over time.

In Housing Standards 2003/2004 [Lux et al. 2004], the next publication, the pros and cons of housing policy based on the privatisation of the municipal housing stock were compared with a housing policy in which a shift from the firstgeneration rent-control system to the second-generation rent-control system is given priority. Lux et al. [2004] recommended using this shift to preserve the thus far relatively important rental-housing sector in the Czech Republic, and 
thereby slowing down the process of privatising municipal rental housing. One part of the book concentrates on comparing two main forms of public support designed to increase the financial affordability of rental housing that are used in most developed countries: social housing and the housing allowance. Based on the experiences of the developed countries, the authors attempted to answer the following questions: what form should the second-generation rent control take in the Czech Republic, what form should social housing take (which entities should be allowed to operate social housing, how should the construction of social dwellings be funded, how should social dwellings be allocated, how should rent levels be determined in social dwellings, etc.), and what housing allowance system would work best in the Czech environment.

Rent deregulation brings about an increase in public budget incomes (higher income from collected rent), but it can also result in increased costs [Lux et al. 2004]. Such costs can include, for example, housing allowance payments, rental housing residualisation (e.g. the loss of rent from vacant dwellings), and the costs derived from pension and social benefit uprating when the increase in rents is reflected in the Consumer Price Index. The sum of public costs, which, in addition to those mentioned above, include operating subsidies to municipalities to balance the difference between cost rent and actually paid rent, changes depending on the speed of rent deregulation. To a certain point, total public costs fall as rent increases, and at that point they start growing or remain at an approximately stable level. The goal of Housing Standards 2003/2004 [Lux et al. 2004] was to estimate at what rent level total public costs would be lowest and in this way to determine the optimal timing for the rent deregulation process in the Czech environment.

The survey 'Housing Attitudes in the Czech Republic 2001' revealed that in 2001 the number of people living in the owner-occupied housing sector increased. There was a clear trend of a growing preference for owner-occupied housing (people's intentions with regard to moving in the near future were almost exclusively connected with owner-occupied tenure, and most people think that owneroccupied housing is the type of housing in which they would to live their lives). Owner-occupied housing is what most Czech citizens are aiming to attain [Lux et al. 2002]. The financing of owner-occupied housing is one of the main topics of the third and final publication in the Housing Standards series. The publication Housing Standards 2004/2005: Financing Housing and Refurbishing Housing Estates [Lux et al. 2005] focuses mainly on the evaluation of the efficiency of marketbased housing finance in the Czech Republic, for example, mortgage loans and building savings. The second main topic of this study is the refurbishment of the pre-fab housing estates in the countries of the EU and in the Czech Republic.

The first part of the publication is devoted to monitoring and analysing house prices. A basic overview of the types of price indices used in the advanced countries of the EU is presented along with a description of their individual features, advantages, and disadvantages. The first part also contains information on the house price indices that currently exist in the Czech Republic and it closes 
with an analysis of price developments in the residential housing market in the Czech Republic by using data from the Czech Statistical Office (ČSÚ) and the Institute of Regional Information (IRI). In the second part, the study observes the efficiency of market-based housing finance in selected advanced countries, selected transition countries, and finally it focuses on the situation in the Czech Republic. In the majority of transition countries, particularly during the first decade of the transformation, the demand for mortgage loans was low and mainly limited to the wealthiest part of the population. Even once macro-economic stability had been established in several post-communist countries in the second half of the 1990s, the growth in demand was relatively gradual and slow. The development and spread of market-based housing finance depends essentially on the establishment of macro-economic stability and amendments to legislation. The high share of existing owner-occupied housing is an accelerator rather than a necessary precondition.

Based on the 'Housing Attitudes in the Czech Republic 2001' survey, Lux et al. [2005] concluded that in Czech society socio-cultural factors are definitely influential on the decision of whether to use mortgage loans or not. The authors also compared the level of Czech household mortgage debt with the situation in other selected European countries (according to the data from the European Central Bank) and quoted some of the conclusions from a study conducted by the Czech National Bank (ČNB), which examined the impact of debt financing on household consumption. The principal finding in the ČNB study was that general disposable income is a decisive factor in the consumer decisions of Czech households, and that the influence of real interest rates and loan supply on household consumption expenditures remains weak. The aim of this part of the Housing Standards study, however, was to obtain an idea about how efficient the system of market-based housing finance in the Czech Republic is as a whole, and, using the knowledge of how the systems work in the 'old' EU member states and of the efficiency evaluation methods used there, to point out its potential weaknesses and shortcomings. The conclusions of the analysis using both questionnaire and qualitative survey methods indicate that in general there is a relatively high level of intermediation efficiency in the field of market-based housing finance in the Czech Republic, but some smaller problems were detected, and solving these could contribute to greater efficiency.

The Socio-Economics of Housing team has participated in several international housing research projects. Its members, Martin Lux and Petr Sunega, are regular participants in the international conference of the ENHR (European Network for Housing Research), and with the support of the Ministry for Regional Development the team organised an international seminar on 'Social Housing in Europe 2000'. The team took part in the SUREURO project (Sustainable Refurbishment Europe). SUREURO is an acronym for one of the largest research projects supported under the 5th Framework Programme of the European Commission. Its main objective was the development of methodical and operative 
tools for sustainable refurbishment of existing large housing estates in Europe. The Czech part of the project was titled 'SUREURO CZ NAS'. The Socio-Economics of Housing team prepared a manual on tenant participation in the refurbishment of municipal housing estates in the Czech Republic, which contains useful information, best practices, a typology, and tools of tenant participation for use by local municipal management companies responsible for the maintenance and management of housing funds and for cooperation with tenants. These guidelines take into account both the experience of the countries participating in the main SUREURO project and the experience of Czech not-for-profit associations involved in public work and local democracy projects.

At present the Socio-Economics of Housing team is working on projects in a slightly different area of housing research. 'The Analysis of Housing Policy Measures Aimed at Supporting Work Flexibility in the Czech Republic (2005-2006)' is a current project funded by the Ministry for Regional Development now reaching completion. The main goal of the project was to analyse the significance in the Czech Republic of the relationship between labour mobility, on the one hand, and housing tenure and existing and potential housing policy tools, including rent regulation, on the other. The weight of the direct influence of housing tenure on potential labour mobility is estimated by testing it along with the influence of other significant factors that may present obstacles to labour mobility, such as specific cultural and social norms.

'The Housing Market in Prague from the Perspective of Economic Sociology: "Transitive" Factors behind the High Prices of Owner-Occupied Housing (2006-2008)', funded by the Grant Agency of the Czech Republic, is another current project, and unlike other research it focuses primarily on an analysis of the housing supply. The aim of the project is to determine whether there exist any 'transitive' (more precisely, institutionally and culturally specific) factors that are capable of contributing to the limited affordability and high prices of owner-occupied housing in Prague, and specifically to the high value of the price-to-income ratio indicator for old and new owner-occupied flats in apartment buildings in Prague, and to estimate the influence of such factors along with the potential impact of their disappearance or elimination. The Housing Standards series of publications will continue within the framework of this project.

Martina Mikeszoví is a PhD student in the Department of Sociology, Faculty of Philosophy and Arts, Charles University in Prague, and since 2006 she has been a junior researcher at the Institute of Sociology of the Academy of Sciences of the Czech Republic. She is cooperating in work on the project "The Housing Market in Prague from the Perspective of Economic Sociology: "Transitive" Factors behind the High Prices of OwnerOccupied Housing'. 


\section{Publications by the research team (chronologically)}

Lux, M. 2000. The Housing Policy Changes and Housing Expenditures in the Czech Republic. Sociologické texty/Sociological Papers 00:1. Prague: Institute of Sociology, Academy of Sciences of the Czech Republic.

Lux, M. and P. Burdová. 2000. Výdaje na bydlení, sociální bydlení a napětí na trhu s bydlením (mezinárodní komparace a polistopadový vývoj v ČR). (Housing Expenditures, Social Housing and Tensions on Housing Market - Comparative View). Prague: Hlavka Foundation.

Lux, M. 2001. 'Social Housing in the Czech Republic, Poland and Slovakia.' European Journal of Housing Policy 1 (2): 189-209.

Lux, M. (ed.) 2002a. Housing Policy: An End or a New Beginning. Budapest: Open Society Institute, Local Government Initiative.

Lux, M. 2002b. Spokojenost českých občanui s bydlením. (Satisfaction with Housing among the Czech Population) Sociologické texty/Sociological Papers 02:3. Prague: Institute of Sociology, Academy of Sciences of the Czech Republic.

Lux, M., D. Cermák, M. Obadalová, P. Sunega and Z. Vajdová. 2002. Bydlení - věc veřejná. (Housing - Res Publica). Prague: Sociologické nakladatelství.

Lux, M. 2003. 'Efficiency and Effectiveness of Housing Policies in the Central and Eastern Europe Countries.' European Journal of Housing Policy 3 (3): 243-265.

Lux, M., P. Sunega, T. Kostelecký and D. Čermák. 2003. Standardy bydlení 2002/03: Finanční dostupnost a postoje občanů. (Housing Standards 2002/03: Financial Affordability and Attitudes towards Housing). Prague: Institute of Sociology, Academy of Sciences of the Czech Republic.

Sunega, P. 2003. Objektivní a subjektivní hodnocení finanční dostupnosti bydlení v ČR $v$ průběhu 90. let. (Objective and Subjective Evaluation of Financial Affordability of Housing in the Czech Republic in the Last Decade of the 20th Century)

Sociologické texty/Sociological Papers 03:5. Prague: Institute of Sociology, Academy of Sciences of the Czech Republic.

Lux, M. 2004a. Quasi-Normative Approach to Housing Affordability. Glasgow: University of Glasgow.

Lux, M. 2004b. 'Housing the Poor in the Czech Republic: Prague, Brno and Ostrava.' Pp. 23-65 in Too Poor to Move, Too Poor to Stay, edited by J. Fearn. Budapest: Local Government and Public Service Reform Initiative, Open Society Institute.

Lux, M., P. Sunega, T. Kostelecký, D. Čermák and P. Košinár. 2004. Standardy bydlení 2003/2004: Bytová politika v ČR: efektivněji a cíleněji. (Housing Standards 2003/2004: Housing policy in the Czech Republic: More Efficiently and More Effective) Prague: Institute of Sociology, Academy of Sciences of the Czech Republic.

Lux, M., P. Sunega, T. Kostelecký, D. Čermák and J. Montag. 2005. Standardy bydlení 2004/2005: Financování bydlení a regenerace sídlišt'. (Housing Standards 2004/2005: Financing Housing and Refurbishing Housing Estates). Prague: Institute of Sociology, Academy of Sciences of the Czech Republic. 